\title{
A DIFFERENTIAL STAINING FOR LIVING AND DEAD LARVAL TREMATODES
}

\author{
KEIICHI ISHII \\ The National Institute of Health, Tokyo
}

(Received: February 24th, 1953)

In the course of various experiments on larval trematodes, we often confront the necessity for determining their death. In such cases the movement of body, cilia or flame-cells is used commonly as an indicator to determine their death by many parasitologists. However, such movements appear to be not always coincident with the time of the death, consequently results of the diagnosis by such a technic seems to be not so exact. The purpose of this work is to find a simple and more reliable technic for determining the death of larval trematodes. For the diagnosis of cellular death, following technics have been proposed by previous investigators:

1. Morphological degenerating process.

2. Changes of movement or locomotion of cell.

3. Vital staining.

4. Permeability of chemical agents.

5. Microestimation of electric changes on cell (e.g. $\mathrm{pH}, \mathrm{rH}$ ).

6. Changes of localization or activity of unstable substances in the cell (e.g. enzymes, nucleic acids, etc.).

7. Plasmolysis (especially on plants).

8. Changes of ultraviolet absorption.

9. Changes of reflex index of cell.

In the case of larval trematodes, very frequently it is necessary to determine their death in large number with a limited short time. For this purpose, the method 1) is inconvenient because very often the initial sign of the degenerating process can only be recognized a certain time after the cell died. With method 2) the result is very often uncertain as the stopping of cell movement is not always coincide with its death. With the method 3) or 5), the difference in color between the living and the dead cells is often sufficient for a reliable diagnosis of death, but the technic is too much complicated for the present purpose. And the method of 6), 8) or 9) necessitates several costly apparatus or complicated treatments, although the reactions are sharp and accurate.

So the author tried to apply a classical simple method combining 3) with 4) proposed by Luyet (1937). The principle of this method is as follows: First apply a solution of neutral red which penetrates both the living and the dead cells and then add a $\mathrm{KOH}$ solution to them. So $\mathrm{KOH}$ enters into the dead cells only and modifies the color of the stain. 
The author applied this method with slight modifications on various larval trematodes; miracidia of Fasciola hepatica, cercariae and miracidia of Schistosoma japonicum, cercariae of Exorchis major, Cercaria incerta Faust, 1924, and Cercaria nipponensis Faust, 1924, and always was able to obtain good results. Table 1 showed the results by this method compared with those of ciliary and flame-cell movements on miracidia of liver fluke. One hundred moving miracidia were first treated by one per cent $\mathrm{NaCl}$ for five min. Before treatment the body cilia and flame-cells of all miracidia were moving. By these pretreatments among 100 miracidia none were moving their body cilia and 13 were moving their flame-cell cilia. Then the medium was washed out by centrifuging (2500 $\mathrm{RPM} / 3 \mathrm{~min}$.) and the miracidia were stood for about five min. No ciliary movement was able to be observed in all miracidia while in 81 among 100 miracidia flame-cell movement was observed. When applying the neutral red$\mathrm{KOH}$ reaction on these 100 miracidia 97 took a bright red tint and proved to be living. Indeed, after leaving materials treated by the same procedure for about 30 min., usually about 90 to 100 per cent miracidia were observed swimming. Thus the present method is considered to be more accurate and convenient than that by the observation of ciliary or flame-cell movement, and proved to be able to apply not only for cells but for larval trematodes.

Table 1. The results of the reaction of neutral red-KOH method and that of the ciliary and flame-cell movements on miracidia of liver fluke.

\begin{tabular}{|c|c|c|c|c|c|c|c|c|}
\hline & \multicolumn{3}{|c|}{$\begin{array}{c}\text { Ciliary } \\
\text { movement }\end{array}$} & \multicolumn{3}{|c|}{$\begin{array}{l}\text { Flame-cell } \\
\text { movement }\end{array}$} & \multicolumn{2}{|c|}{$\begin{array}{l}\text { Neutral red }= \\
\text { KOH reaction }\end{array}$} \\
\hline & Moving & $\begin{array}{l}\text { Stop- } \\
\text { ping }\end{array}$ & $\begin{array}{l}\text { Unde- } \\
\text { term. }\end{array}$ & Moving & $\begin{array}{l}\text { Stop- } \\
\text { ping }\end{array}$ & $\begin{array}{l}\text { Unde- } \\
\text { term. }\end{array}$ & $\begin{array}{c}\text { Red } \\
\text { (Living) }\end{array}$ & $\begin{array}{l}\text { Yellow } \\
\text { (Dead) }\end{array}$ \\
\hline $\begin{array}{l}\text { In } 1 \% \mathrm{NaCl} \\
\text { for } 5 \mathrm{~min} \text {. }\end{array}$ & 0 & 98 & 2 & 13 & 82 & 5 & & \\
\hline $\begin{array}{l}5 \text { min. after } \\
\text { washing }\end{array}$ & 0 & 100 & 0 & 81 & 15 & 4 & 97 & 3 \\
\hline
\end{tabular}

The modified procedure is as follows: Mix equal volume of medium containing larvae and freshly prepared 0.1 per cent aqueous solution of neutral red with stirring and agitation. Thirty sec. to one min. later, add one-half volumes of 0.1 per cent $\mathrm{KOH}$ solution into the mixture. After these simple procedures the living organisms take a bright red tint (fig. 1) and the dead take an intense orange-yellow tint (figs. 3 and 4) within several seconds. Very often there appear gradual intermediate tints corresponding to the vitality of the organisms (fig. 2).

When the concentration of neutral red is higher, the color contrast becomes sharper, but at the same time the more toxic effect upon the larvae occures and precipitate of dye formed by $\mathrm{KOH}$ increases and disturbes the observation. Before treatment, it is necessary to estimate the toxity of this mixture upon the living materials to which the examination are to be made, because the toxic 
effects should be variable as materials varied. The diagnosis of death should be carried out before all organisms turned to orange-yellow in color. It takes for twenty to thirty min. before all larvae take orange-yellow in color when larval trematodes are treated by the mixture with the concentration in the above receipt. Provided that the diagnosis is carried out within five to ten min., its toxic effects upon larvae will usually be prevented.

When the medium is strong acidic or alkaline, or contains a certain amounts of some salts, the result by this method will be disturbed unless the organisms are prewashed by centrifugation.

Sincere thanks are due to Dr. Yoshitaka Komiya, Chief of the Division, who extended invaluable guidance to this work. Thanks are due to Mr. Jiro Ito, a Member of the Division, who kindly determined species of cercariae used, and also to Mr. Kazuo Yasuraoka for supplying miracidia of liver fluke used in this study.

\section{REFERENCES}

1. Guilliermond, A. Les constituants morphologiques du cytoplasme. Paris, 1935.

2. Lee, A. B. The microtomist's vade-mecum. ed. 11, 1950.

3. Lindegren, C. C. The Yeast cell. p. (5-1)-(5-2), 1949.

4. Luyet, B. J. Differential staining for living and dead cells. Science, 85: 106, 1937.

5. Péterfi, T. Methodik d. wiss. Biol. Bd. 1, 1928. 

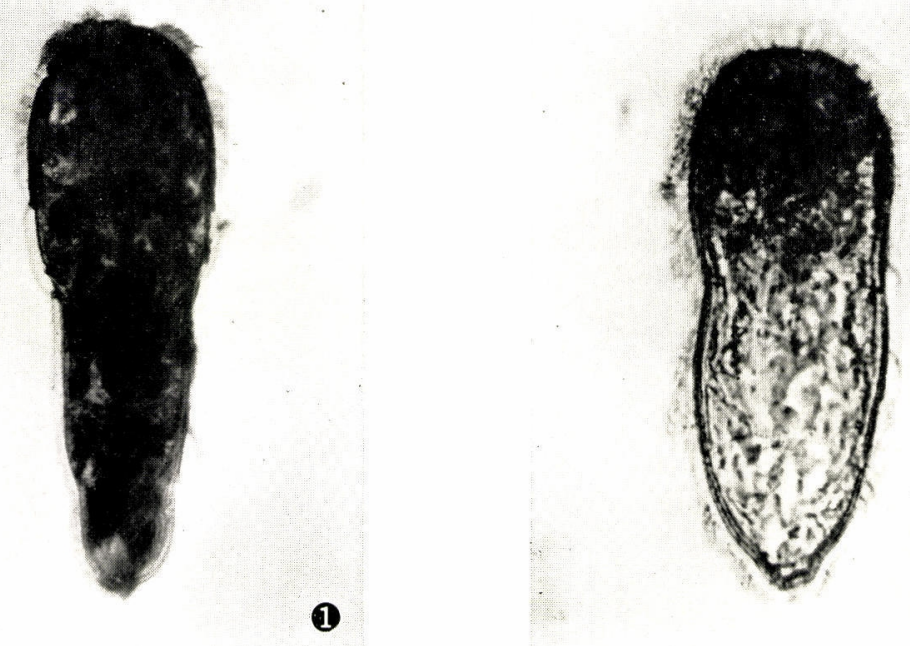

2
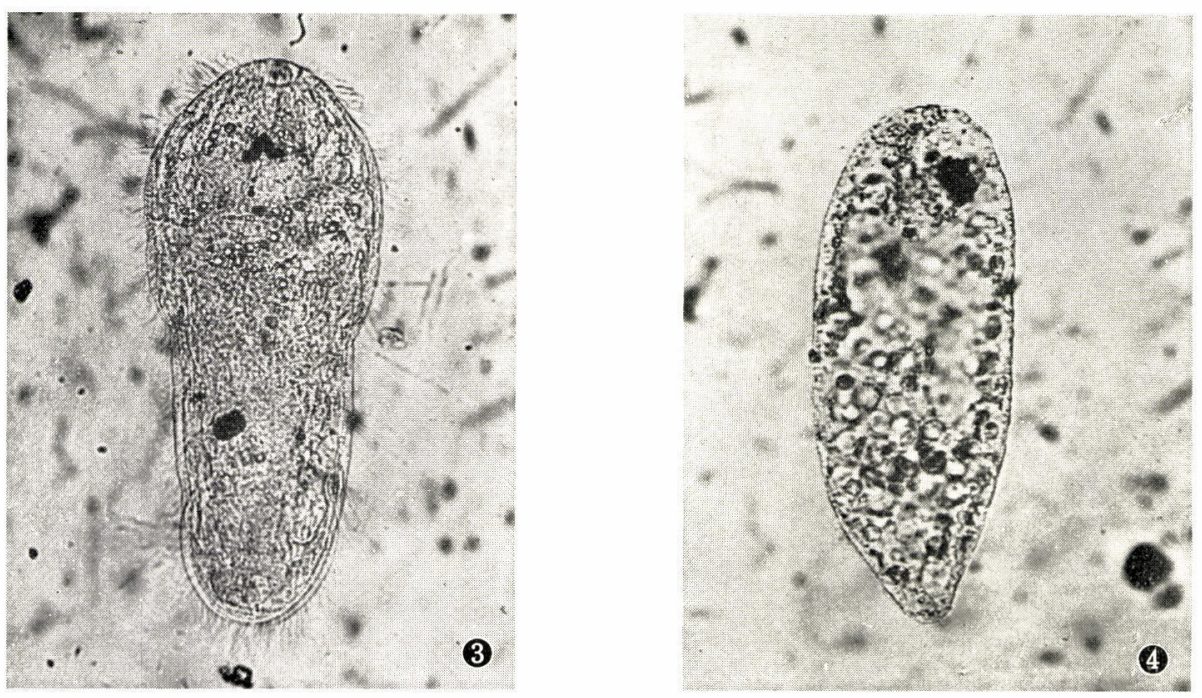

Explanation of the plate

Fig. 1. A miracidium of liver fluke; stained dark red tint (living reaction).

Fig. 2. Ibid.; intermediate type after prolonged immersion in the mixture, the anterior part of body staining red and the posterior part of body staining yellow.

Fig. 3. Ibid.; pretreated with osmic acid vapor, stained yellow (dead reaction).

Fig. 4. Ibid.; dead one by the exposing of heat, stained yellow (dead reaction). 